\title{
Morphometric Analysis of Lake Langano Watershed using Geographic Information System
}

\author{
Shimelis Sishah \\ School of Social Science and Humanities, Arsi University, PO box 09, Bokoji, Ethiopia \\ Zenebe Reta \\ School of Social Science and Humanities, Metu University, PO box xxx, Metu, Ethiopia
}

\begin{abstract}
An understanding of watershed characteristics like areal, linear and relief aspect has paramount significance for watershed planning and management. An automatic extraction of these characteristics from digital elevation model is so effective and efficient. The main objective of this research work was Morphometric analysis of Lake Langano watershed characteristics from Digital Elevation model using GIS. This research work employs an automatic extraction of hydrological characteristics using Geographical Information system. The results of finding show that the watershed has highly permeable soil type which absorbs the water passing over the soil. Drainage texture of the watershed is very coarse and the watershed is less affected by erosion. There is high runoff in the watershed due to large number of overland flow length. The shape of the watershed is elongated shape and experiences low peak flow over longer duration of time. Circulatory value of the watershed indicates that lake Langano watershed is not under flood risk. Relief characteristics of the watershed indicate that most part of the watershed is characterized by gentle slope and the peak of south eastern part is characterized by steep slope.
\end{abstract}

Keywords: DEM (digital elevation model), GIS (Geographic Information system), Morphometric analysis, Watershed characteristics.

DOI: $10.7176 / \mathrm{JEES} / 10-11-03$

Publication date: November $30^{\text {th }} 2020$

\section{Introduction}

Watershed is defined as any surface area from which run-off (water) resulting from rainfall/snow melt is collected and drained through a common confluence outlet point. Hydrologically, watershed is an area from which the runoff drains through a particular point in the drainage system (Das G, 2004). Watershed comprises surface water, groundwater and other natural resources, which are influenced by human activities. Quality and quantity of downstream has direct connection with the upstream activity of stream. The drainage basin is used as an ideal areal unit for Geo-morphometric analysis because it has inherent limited, convenient and usually clearly defined and unambiguous topographic unit (Martinez et al. 1998). Water is the principal motivating and integrating factor in hydrologic response studies. The concept of a watershed inherently integrates the upstream with the downstream through the flow of this central resource as part of the general hydrological cycle. A number of villages in a watershed often share the same stream as their water source. However, stream flow usually has high seasonal variability, and seasonal local water scarcity is a problem faced by many farmers in small watersheds (Jamtshoand Gyamtsho2003).

The natural region for water resources planning and development is often the river basin. River basins provide a geographic and functional context for many water-related purposes. Most water projects, particularly reservoirs, can serve more than one of the basic purposes such as water supply, irrigation, hydroelectric energy, navigation, flood mitigation, recreation, pollution control, and wildlife conservation (Linsley et al. 1992). Characterization of watershed is a necessary and important step in planning and management of a watershed. Defining the geographic boundaries of watersheds and sub-watersheds helps in gathering and evaluating data for watershed management (Rupesh Rathore et al. 2018). The measurement and mathematical analysis of the configuration of the earth's surface and of the shape and dimensions of its landform provides the basis of the investigation of maps for a Geomorphological survey (Bates \& Jackson, 1980). Information on topographic characteristics of the watershed helps in determining runoff and sedimentation to the outlet of the watershed.

Although watershed delineation at micro level (sub-watershed) is essential for effective planning and watershed management program, watershed characteristics such as size, slope, shape, drainage density, land use/land cover, geology and soils, and vegetation are important factors affecting various aspects of runoff (Rambabu Palaka and G. Jai Sankar, 2014). The Ziway-Shala lake basin system includes four present-day residual lakes, from north to south, Lake Ziway, Lake Langano, Lake Abijata, and Lake Shala respectively (Mekin et al. 1976). Lake Langano watershed is one of the basin watersheds formed from the outlet point of drainage network at north eastern part of Langano Lake. The boundary of the watershed is delineated by rift valley lakes basin authority. However, analysis of the Lake Langano watershed characteristics in terms of linear, areal and relief aspect were not explicitly determined yet. Therefore, the main objective of this research work is morphometric 
analysis of Lake langano watershed using Geographic Information System as a tool. Specifically, this research work is intended to determine and quantify Areal, Linear and Relief aspects of Lake Langano watershed for better planning and management of Lake Langano watershed.

\section{Methods}

\subsection{Study Area}

Lake Langano watershed is one of Zeway-shala lakes basin watersheds which is located at the northern part of great Ethiopian rift valley which covers an area of $2035 \mathrm{~km}$ square. Lake Langano watershed, falls between $7^{\circ} 10^{\prime} 00^{\prime \prime}-7^{\circ} 50^{\prime} 00^{\prime \prime}$ latitude and $38^{\circ} 40^{\prime} 00^{\prime \prime}-39^{\circ} 10^{\prime} 00^{\prime \prime}$ longitude (Fig. 1). The watershed stretches from the edges of the West Arsi Mountains in the southwestern and east showa mountains of Adami Tullu Jido Kombolcha in north eastern, rising over $4023 \mathrm{~m}$ above sea level (masl).

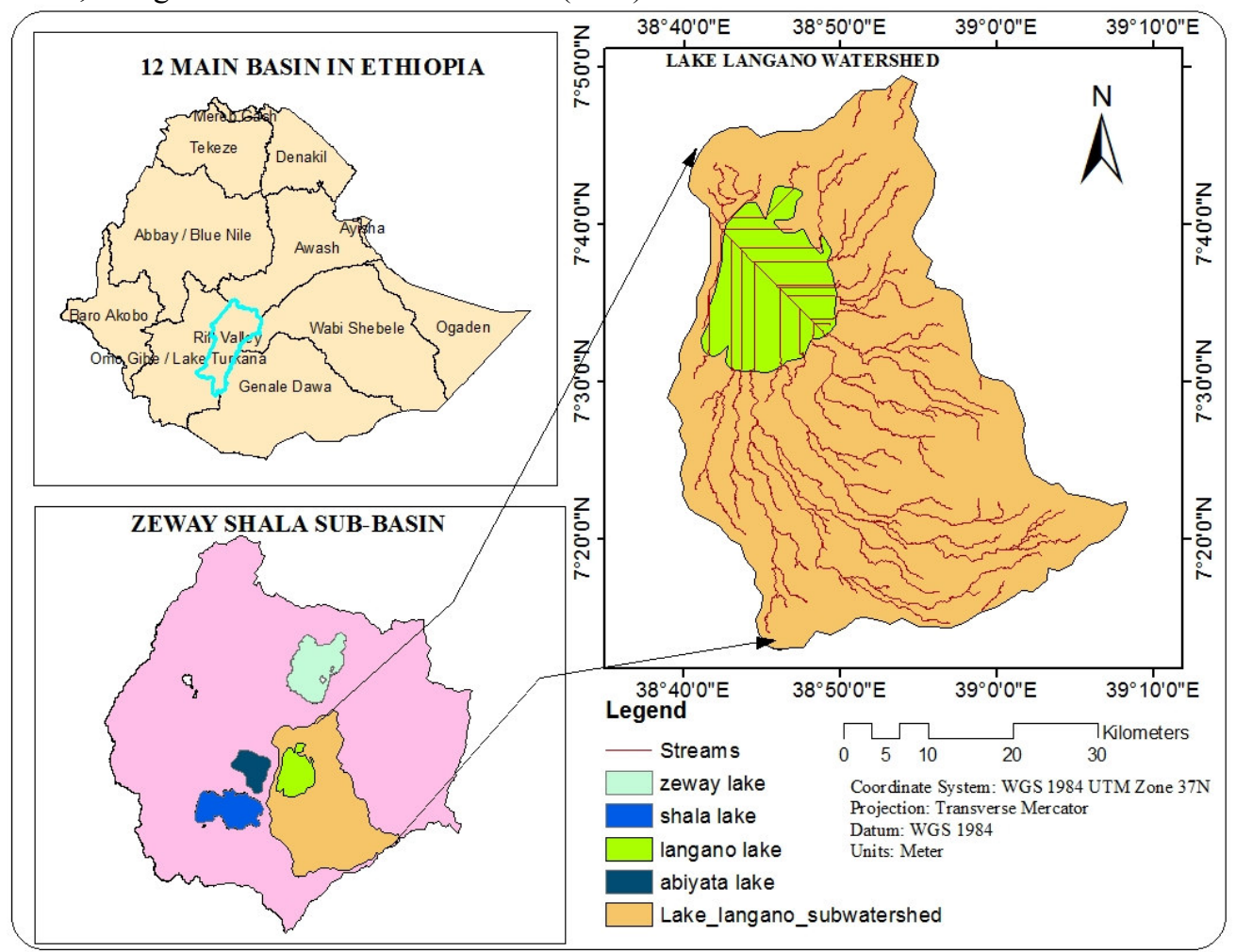

Figure 1: Study area

The north eastern part of the watershed is totally covered by Lake Langano. The entire of the watershed is covered by sparse acacia trees, and extensive cultivated field crop. The watershed inhabits millions of human and livestock population. The watershed does not have uniform climatic conditions. As the intensity, duration and frequency of rainfall events vary in the watershed throughout the year, both dry (locally named as Bega from January - May) and rainy (locally named as Kiremt from June- September) seasons are exchanged over the watershed.

\subsection{Data source}

To investigate watershed characteristics, both primary and secondary data were gathered from different sources. Primary data was collected in the field using Global Positioning System (GPS) to determine the watershed outlet point. In addition, GPS points gathered from the field was used as verification. Secondary data like DEM (Digital Elevation Model) was obtained from United States Geological Survey (USGS) freely. Now a days, Shuttle Radar Topography Mission (SRTM) obtained elevation data on a near-global scale to generate the most complete highresolution digital topographic database of Earth. The SRTM provides a number of DEM resolution outputs which is freely available in USGS websites. DEM (30 meter) was downloaded from USGS website (www.usgs.gov ) for the study area. Five tiles (scene) DEM were needed to cover the whole area of the lake basin and all the scenes are downloaded from USGS website free of charges.

\subsection{Data Analysis}

\subsubsection{DEM Preprocessing}

DEM data downloaded from USGS website needs preprocessing before being directly in use as an input data. Raw DEM data needs transformation of world reference system to local projection system. In this case, downloaded 
DEM was in Geographic Coordinate system and is projected to local Adindan datum. This helps to align the DEM together with other datasets in order to facilitate spatial analysis of input data. DEM was clipped with the extent of the study area in order to reduce computational tasks for the whole area.

\subsubsection{DEM Analysis}

Preprocessed DEM of the study area was analyzed using Hydrological tool in ArcGIS 10.6.1 software. DEM of the study area was first need be to filled in order to remove any sinks in the DEM. Filling DEM sink provides sink free DEM which can be used as in input to derive flow direction of the study area. Flow direction tells as the direction of flow from every cell in the raster for hydrologic characteristics. Flow accumulation was generated from flow direction to determine accumulated flow as the accumulated weight of all cells flowing into each down slope cell in the DEM raster.

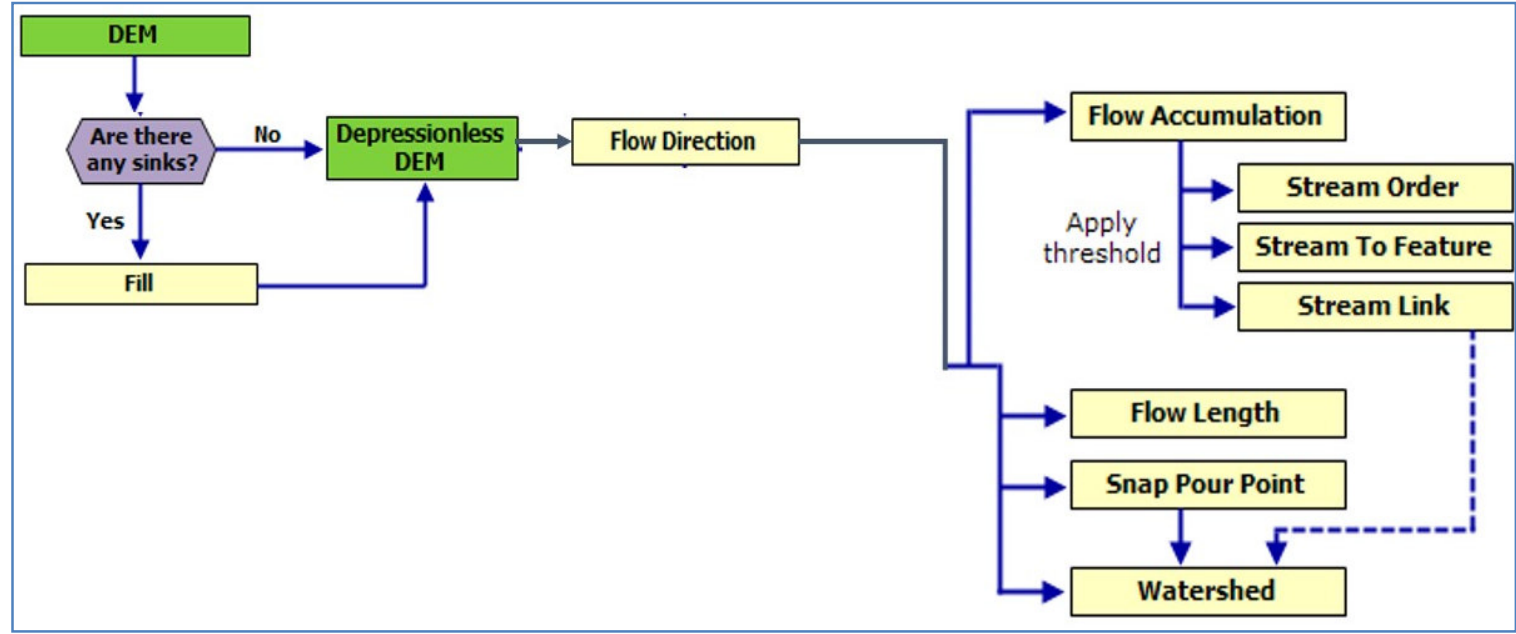

Figure 2 Flow chart that depicts Hydrological analysis of Lake langano watershed [source: ESRI]

Linear aspects of the watershed such as stream order and stream link are derived from flow accumulation. The overall DEM processing for watershed characteristics analysis is depicted in Figure 2 which is adapted from ESRI.

\subsubsection{Watershed Morphometric analysis}

Morphometric analysis is referred to the quantitative evaluation of characteristics of the earth surface and any landform unit. The composition of the stream system of a drainage basin is expressed quantitatively with stream order, drainage density, bifurcation ration and stream length ratio (Horton, 1945). There are basically three important aspects used for doing Morphometric analysis of a basin. These are linear aspects, Areal aspects and Relief aspects. Linear aspects give the information about one dimensional parameter like: Stream Order, Stream Number and Bifurcation Ratio. Areal aspects deal with two dimensional parameters like: Drainage Density, Stream Length, Stream Length Ratio, Drainage Texture, Stream Frequency, Circularity Ratio and Form Factor. Relief Aspects deals with three dimensional parameters like: Relief, Relief Ratio, Slope and Gradient Ratio. For Lake Langano watershed, three types of Morphometric analysis were selected. The mathematical formulae for Morphometric parameter analysis were adapted from different literatures (Table1).

Table 1: Formulae for calculation of different watershed parameters

\begin{tabular}{|l|l|l|l|}
\hline No. & Morphometric parameter & Formula & Reference \\
\hline 1 & Stream order & Hierarchal rank & Strahler $(1952)$ \\
\hline 2 & Stream Length & Length of each N order & Schumn $(1956)$ \\
\hline 3 & Bifurcation ratio & $\mathrm{Rb}=\mathrm{N} / \mathrm{N}+1$ & Strahler $(1957)$ \\
\hline 4 & Drainage density & $\mathrm{Dd}=\sum \mathrm{L} / \mathrm{A}$ & Strahler $(1964)$ \\
\hline 5 & Stream frequency & $\mathrm{Fs}=\sum \mathrm{N} / \mathrm{A}$ & Horton $(1932)$ \\
\hline 6 & Drainage texture & $\mathrm{Dt}=\mathrm{N} 1 / \mathrm{P}$ & Horton $(1945)$ \\
\hline 7 & Form factor & $\mathrm{Ff}=\mathrm{A} /(\mathrm{Lb})^{2}$ & Miller $(1932)$ \\
\hline 8 & Circulatory Ratio & $\mathrm{Cr}=4 \pi \mathrm{A} /(\mathrm{P})^{2}$ & Strahler $(1964)$ \\
\hline 9 & Elongation ratio & $\mathrm{Er}=2 \sqrt{ }(\mathrm{A} / \pi) / \mathrm{Lb}$ & Horton $(1945)$ \\
\hline 10 & Length of overland flow & $\mathrm{Lo}=\frac{1}{2}(\overline{\mathrm{L}})$ & \\
\hline 12 & Elevation & Elevation number in meter & \\
\hline 13 & Slope & (rise/run) $\mathrm{x} 100$ & \\
\hline
\end{tabular}

*N=stream number, $\mathrm{L}=$ stream length, $\mathrm{A}=$ area of watershed, $\mathrm{P}=$ perimeter of watershed, $\mathrm{L} b=$ length of the basin, $\overline{\mathrm{L}}=$ mean of stream length, $\mathrm{H}=$ maximum elevation, $\mathrm{h}=$ minimum elevation* 


\section{Results and discussion}

\subsection{Linear Aspect}

\subsubsection{Stream order}

Stream ordering is a method of assigning a numeric order to links in a stream network. This order is a method for identifying and classifying types of streams based on their numbers of tributaries. The stream ordering systems has first advocated by Horton (1945), but Strahler (1952) has proposed this ordering system with some modifications. For this research Strahler (1952) method was used for ordering streams along the lake langano watershed. In the Strahler method, all links without any tributaries are assigned an order of 1 and are referred to as first order. The intersection of two first-order links will create a second-order link and also intersection of firstorder with second order results second order. The intersection of two second-order links will create a third-order link. Five types of stream order (First order, second order, third order, fourth and fifth order) was generated for Lake langano watershed.

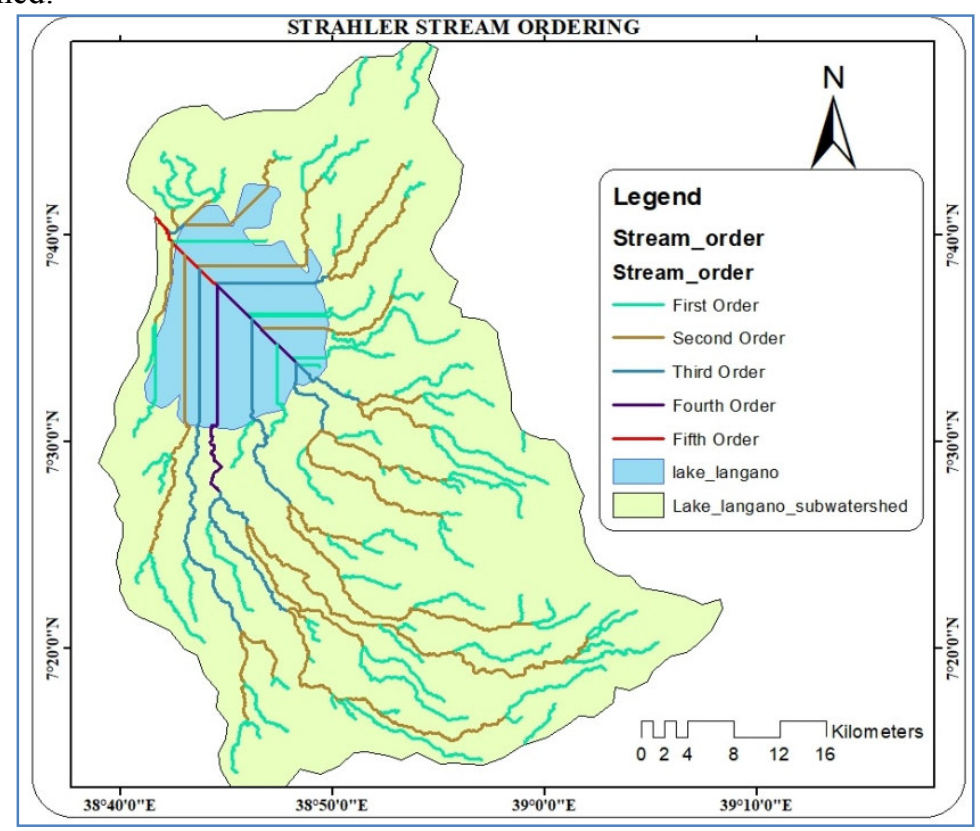

Figure 3 Strahler stream ordering

\subsubsection{Basin length (Lb)}

Schumm (1956) defined the basin length as the longest dimension of the basin parallel to the principal drainage line. Gregory and Walling (1973) defined the basin length as the longest in the basin in which end being the mouth. Basin length can be measured in ArcGIS with distance measuring tool. Length of Lake Langano watershed was measured in ArcMap using distance measuring tool. The longest measured Length of the watershed is $65 \mathrm{~km}$.

\subsubsection{Stream length $(L)$}

The total sum length of each stream order is calculated as summation of each individual segment in that order. Mean stream length of each order is calculated as the total sum of stream length in each order divided by the number of streams in that order. The following table depicts stream length of each order and mean stream length of each stream order for Langano lake watershed.

Table 2: Stream length and mean stream length of each order

\begin{tabular}{|r|r|r|}
\hline & Stream number & Sum length of each order \\
\hline Ftream Order & 84 & 478.24 \\
\hline Second Order & 48 & 324.59 \\
\hline Third Order & 14 & 110.05 \\
\hline Fourth Order & 8 & 30.96 \\
\hline Fifth Order & 8 & 8.31 \\
\hline & & \multicolumn{2}{|c|}{ Mean: -5.87 Total sum: -952.15} \\
\hline
\end{tabular}

\subsubsection{Bifurcation ratio $(\mathrm{Rb})$}

The bifurcation ratio is the ratio of the number of the stream segments of given order to the number of streams in the next higher order. Strahler (1957) demonstrated that bifurcation shows a small range of variation for different regions or for different environment except where the powerful geological control dominates. The bifurcation ratio is dimensionless property and generally ranges from 3.0 to 5.0. The lower values of bifurcation ratio are characteristics of the watersheds, which have suffered less structural disturbances (Strahler1964) and the drainage 
pattern has not been distorted because of the structural disturbances(Nag 1998). In lake langano watershed, the lower values of bifurcation ratio indicate strong structural control on the drainage pattern, while the higher values indicative of watershed that are affected by structural disturbances.

Table 3: Bifurcation ratio

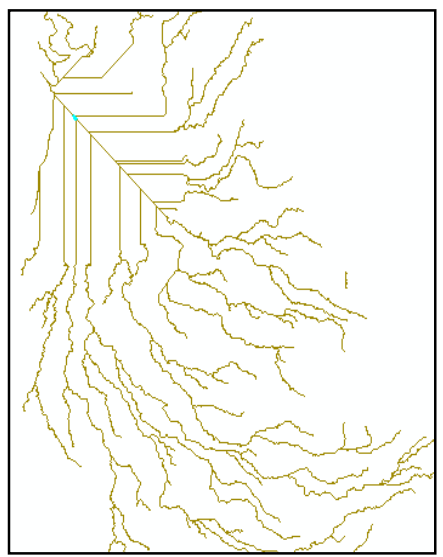

\begin{tabular}{|r|c|c|}
\hline \multicolumn{1}{|l|}{ Stream Order } & Stream number & Bifurcation ratio (Rb) \\
\hline First Order & 84 & - \\
\hline Second Order & 48 & 1.75 \\
\hline Third Order & 14 & 3.42 \\
\hline Fourth Order & 8 & 1.75 \\
\hline Fifth Order & 8 & 1 \\
\hline
\end{tabular}

\subsection{Areal Aspect}

3.2.1. Drainage Density (Dd)

Drainage density (Dd) shows the landscape dissection, runoff potential, infiltration capacity of the land, climatic conditions and vegetation cover of the basin. High drainage density is the resultant of weak or impermeable subsurface material, sparse vegetation and mountainous relief. Low drainage density leads to coarse drainage texture while high drainage density leads to fine drainage texture (Strahler, 1964).

$D d=L / A \quad$ Where $\mathrm{L}=$ Total length of stream, $\mathrm{A}=$ Area of the basin

$$
D d=\frac{952.15}{2035}=0.47
$$

The Line Density tool in ArcMap calculates the density of linear features in the neighborhood of each output raster cell. Drainage density is a better quantitative expression to the dissection and analysis of landforms. Drainage density of Lake Langano watershed was generated from stream channel using stream length field value as an input. According to (Nag 1998), drainage density is an indicator of basin permeability. The results of drainage density for Lake Langano watershed was 0.47 which shows very low and this reveal that the permeability of the soil is very high.

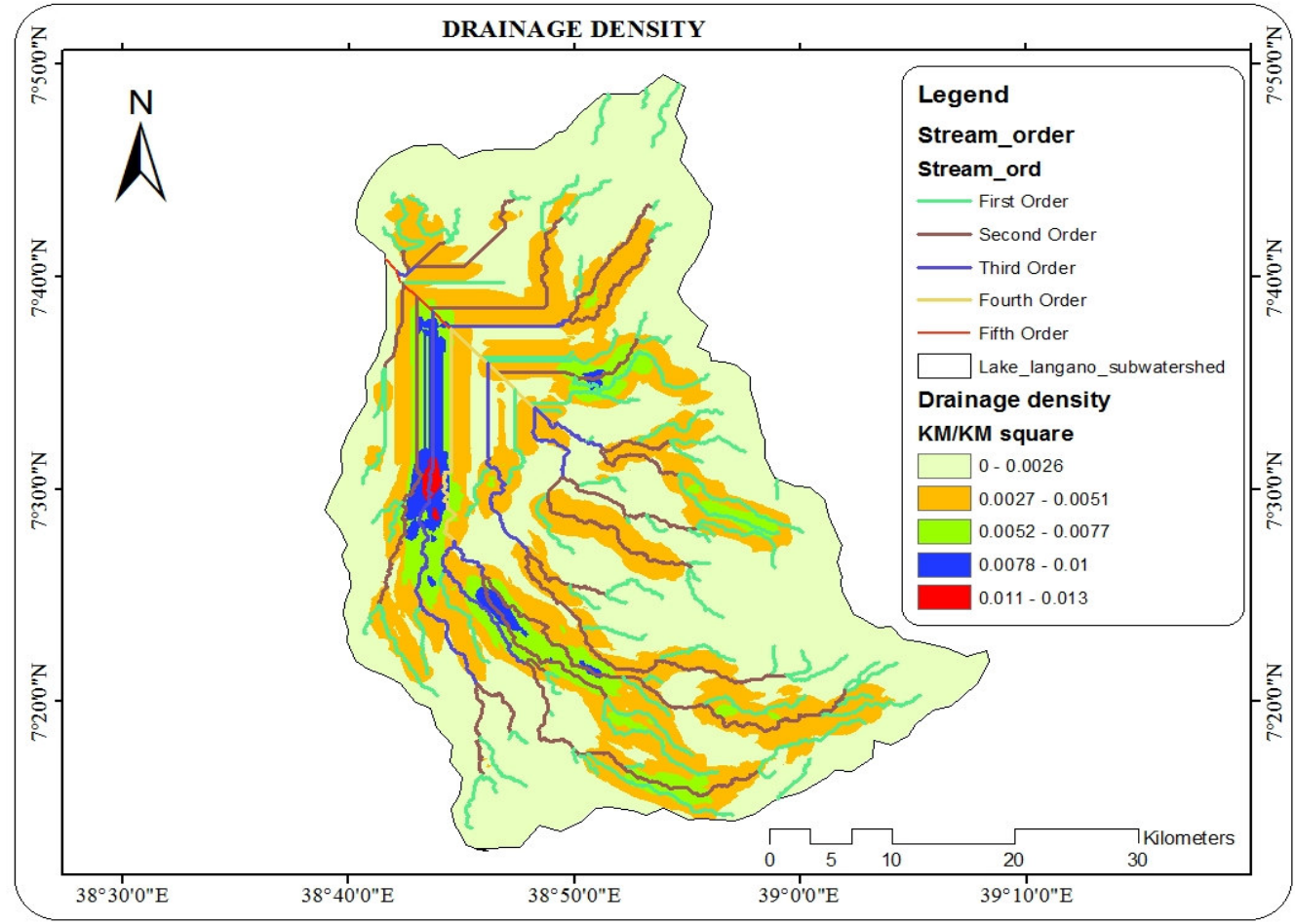

Figure 4: Drainage density 


\subsubsection{Stream frequency (Fs)}

Stream frequency (Fs), is expressed as the total number of stream segments of all orders per unit area. Generally, high stream frequency is related to impermeable sub-surface material, sparse vegetation, high relief conditions and low infiltration capacity (Horton, 1962). The total stream number of Lake langano watershed resulted from five stream order is 162. Subsequently, the total area of the watershed resulted from ArcMap area calculation is 2,035 square kilometer. Stream frequency of Lake Langano watershed is calculated in the following manner.

$F S=N / A \quad$ Where $\mathrm{N}=$ Total number of streams, $\mathrm{A}=$ Area of the basin

\subsubsection{Drainage texture (Dt)}

$$
F S=\frac{162}{2035}=0.079
$$

Horton (1945) defined drainage texture is the total number of stream segments of all order in a basin per perimeter of the basin. More is the drainage texture more will be dissection and leads more erosion. Drainage texture is one of the important concepts of geomorphology which means that the relative spacing of drainage lines. Dra,inage texture is on the underlying lithology, infiltration capacity and relief aspect of the terrain. (Smith, 1950) has classified drainage texture into five different textures i.e., very coarse $(<2)$, coarse (2 to 4$)$, moderate (4 to 6), fine $(6$ to 8$)$ and very fine $(>8)$. Drainage texture of the watershed is calculated as total stream number of all order which is 162 divided by perimeter of the watershed $(216 \mathrm{~km})$. Accordingly, the drainage texture of the watershed is equal to 0.75 which is very coarse according to the definition of (Smith, 1950).

$D t=N / P \quad$ Where $\mathrm{N}=$ Total number of streams, $\mathrm{P}=$ Perimeter of the basin

\subsubsection{Length of overland flow (Lo)}

$$
D t=\frac{162}{216}=0.75
$$

According to (Horton 1945), length of overland flow is determined as half the average distance between stream channels of each order. Length of overland flow is one of the most important variables affecting hydrologic and physiographic development of drainage basin. In Lake Langano watershed, the mean of the stream length is 5. 87. Horton (1945) realizes that length of overland flow determines the surface runoff characteristics. This means that higher length of overland flow shows high surface runoff. So, Lake Langano watershed length overland flow is 2.935 and it shows higher surface runoff in the watershed. Length of overland flow (Lo) for Lake Langano watershed is calculated in the following manner.

$L o=\frac{1}{2}(\bar{L}) ;$ Where, Lo $=$ length of overland flow, L bar $=$ Mean of stream length.

$\mathrm{Lo}=1 / 2(5.87)=2.935 \mathrm{KM}$

\subsubsection{Form factor $(\mathbf{F f})$}

Form factor is defined as the ratio of the basin area to the square of the basin length. The form factor value should be always less than 0.7854 (the value corresponding to a perfectly circular basin). The smaller the value of the form factor, the more elongated will be the basin. Basins with high form factors experience larger peak flows of shorter duration, whereas elongated basins with low form factors experience lower peak flows of longer duration. Calculated area and measured length of the watershed is 2,035 square kilometer and $65 \mathrm{~km}$ respectively. Computed Form factor of the watershed is 0.48 . The result of form factor shows that the watershed is elongated shape starting from initial point of the stream to the outlet point. So, Lake Langano watershed experiences low peak flow over longer duration of time.

$F f=\frac{A}{(L b) 2}$ Where, $\mathrm{A}=$ area of the basin, $\mathrm{Lb}=$ length of the basin

$F f=\frac{2035 \mathrm{~km} 2}{(65 \mathrm{~km}) 2}=0.48$

\subsubsection{Circulatory ratio $(\mathrm{Cr})$}

The circulatory ratio is originally defined by Miller (1953), as the ratio of the area of the basin to the area of the circle having same circumference as the basin perimeter. Circulatory ratio is helpful for assessment of flood hazard. Higher the circulatory value, higher is the flood hazard at the peak time at the outlet point. Circulatory ratio of Lake Langano watershed is 0.54 which is very low compared to the shape of the watershed. Lower circulatory ratio of the watershed shows that the watershed is not as much as under flood risk.

$C r=\frac{4 \pi A}{P 2} \quad$ Where $\mathrm{A}=$ Area of the basin, $\pi=3.14, \mathrm{P}=$ perimeter of the basin

$C r=\frac{4 * 3.14(2035)}{(216 * 216)}=0.54$

\subsubsection{Elongation ratio (Er)}

Schumm's (1956) used an elongation ratio as the ratio of diameter of a circle of the same area as the basin to the maximum basin length. The value of elongation ratio varies from 0 (in highly elongated shape) to unity i.e. 1.0 (in the circular shape). Thus, higher the value of elongation ratio more circular shape of the basin and vice-versa. Values close to 1.0 are typical of regions of very low relief, whereas that of 0.6 to 0.8 are usually associated with high relief and steep ground slope (Strahler, 1964). Computed elongation ratio value for Lake Langano watershed 
is 0.78 which lies between the ranges of 0.6 to 0.8 . According to the value of elongation ratio, Lake Langano watershed is characterized by high relief and steep slope. High relief and steep slope part are located at the south eastern part of the watershed. Whereas the mouth of the watershed is characterized by gentle slope following, flat area of the watershed.

$E r=\frac{2 \sqrt{ }\left(\frac{A}{\pi}\right)}{L b} \quad$ Where $\mathrm{A}=$ area of the basin, $\mathrm{Lb}=$ length of the basin

$\operatorname{Er}=\frac{2 \sqrt{\left(\frac{2035}{3.14}\right)}}{65}=0.78$

\subsection{Relief aspect}

\subsubsection{Elevation}

Elevation is defined as land surface height relative to surface of mean sea level. Digital elevation model data describes continues elevation of the watershed. The highest and lowest elevation of Lake Langano watershed is $4023 \mathrm{~m}$ and $1551 \mathrm{~m}$ respectively. South eastern peak of the watershed is characterized by highest elevation and north eastern part of the entire watershed is characterized by low elevation.

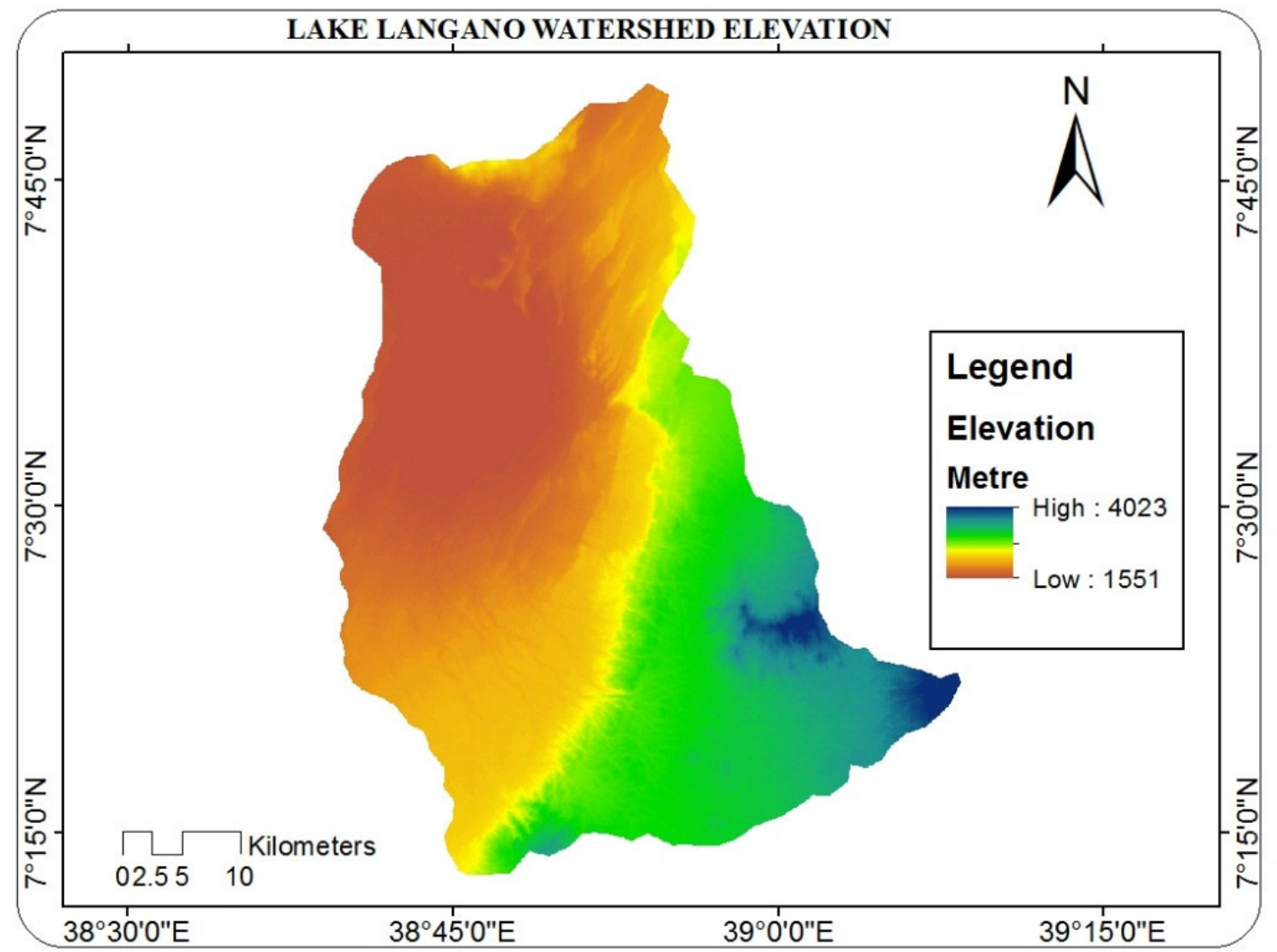

Figure 5: Elevation

\subsubsection{Slope}

Slope describes the incline or steepness of a surface. Slope can be measured in degrees from horizontal (0-90), or percent slope (which is the rise divided by the run, multiplied by 100). Slope of Lake Langano watershed is calculated using percent in ArcGIS 10.6.1 software. 


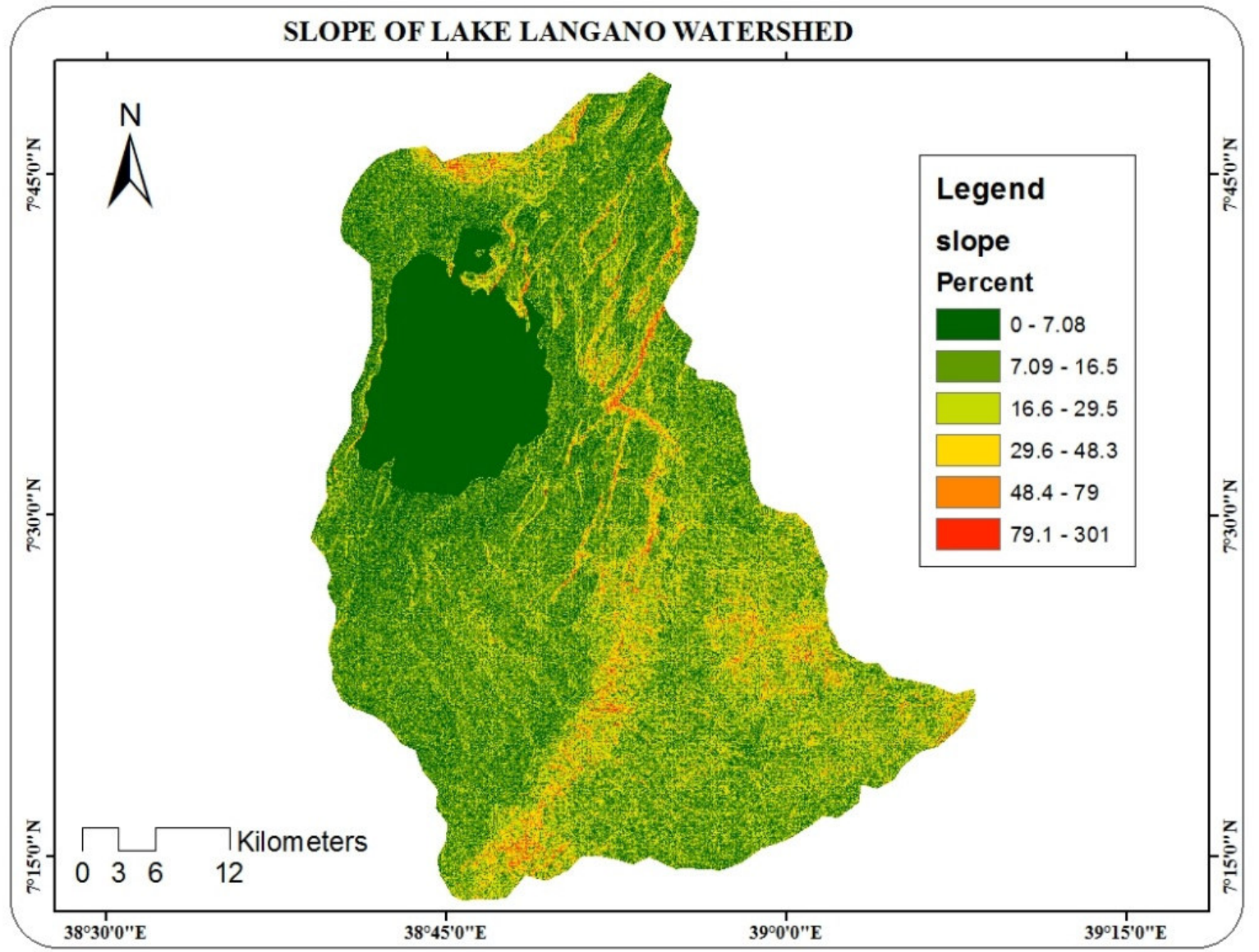

Figure 6: Slope

Table 4: Quantitative results of Lake Langano watershed characteristics

\begin{tabular}{|l|l|l|}
\hline No. & Morphometric parameter & Results \\
\hline 1 & Stream order & Five orders \\
\hline 2 & Stream Length & 952.15 (total length) \\
\hline 3 & Bifurcation ratio & Ranges from 1-3.5 \\
\hline 4 & Drainage density & 0.47 \\
\hline 5 & Stream frequency & 0.079 \\
\hline 6 & Drainage texture & 0.75 \\
\hline 7 & Form factor & 0.48 \\
\hline 8 & Circulatory Ratio & 0.54 \\
\hline 9 & Elongation ratio & 0.78 \\
\hline 10 & Length of overland flow & $2.935 \mathrm{~km}$ \\
\hline 11 & Elevation & Ranges from $1551-4023 \mathrm{~m}$ \\
\hline 13 & Slope & Ranges from $0-300$ percent \\
\hline
\end{tabular}

Source: Own generated

\section{Conclusion}

The hydrologic modeling tools in the ArcGIS Spatial Analyst extension toolbox provide methods for describing the physical components of a surface. The hydrologic tools allow as identifying sinks, determining flow direction, calculating flow accumulation, delineating watersheds, and creating stream networks. Besides hydrological modeling of a given watershed, quantitative assessment of watershed characteristics is an important function. In this study, quantitative Morphometric analysis of Lake Langano watershed was performed. Three aspects of Morphometric analysis were examined to explore Lake Langano watershed characteristics. Lake Langano watershed has five stream orders with predefined threshold value of 1000 pixels. Bifurcation ratio of the stream orders shows that second, fourth and fifth orders have strong structural control on drainage pattern. Whereas, third order have weak structural control and affected by structural disturbance. The watershed has highly permeable soil type which absorbs the water passing over the soil. Drainage texture of the watershed is very coarse and the 
watershed is less affected by erosion. Drainage density is a better quantitative expression to the dissection and analysis of landforms. Drainage density of Lake Langano watershed was generated from stream channel using stream length field value as an input. The results of drainage density for Lake Langano watershed was 0.47 which shows very low and this reveal that the permeability of the soil is very high. There is high runoff in the watershed due to large number of overland flow length. The shape of the watershed is elongated shape and experiences low peak flow over longer duration of time. Circulatory value of the watershed indicates that lake Langano watershed is not under flood risk. Relief characteristics of the watershed indicate that most part of the watershed is characterized by gentle slope and the peak of south eastern part is characterized by steep slope.

\section{Acknowledgments:}

First, I would like to offer my special thanks to almighty God. Secondly, I would like to express my great appreciation to Arsi University, Department of Geography and environmental studies staff for their valuable and constructive suggestions during the planning and development of this research work. Their willingness has been very much appreciated. Finally, my special thanks are extended to Rift valley lakes basin Authority for their willingness in helping me in data collection.

\section{Reference}

Das G, 2004. Hydrology and soil conservation engineering. Prentice Hall of India, New Delhi.

Gregory, K.J and Walling, D.E (1973). Drainage Basin Form and Process- a Geomorphological Approach. London: Edward Arnold.

Honore, G., (1999). Our Land, Ourselves - A Guide to Watershed Management in India, Government of India, New Delhi, p. 238.

Horton R.E., (1932). Drainage basin characteristics. Trans. Am. Geophys Union vol. 13:pp. 350-361

Horton, R. E., (1945). Erosional development of streams and their drainage basins; Hydrological approach to quantitative morphology, Geological Society of American Bulletin, 56, pp 275370

Jamtsho, K and Gyamtsho, T. (2003). Effective watershed and water management at local level: challenges and opportunities. In Regional Workshop on Community Based Natural Resource Management, 4-7 November. Natural Resources Training Institute,Lobeysa, Bhutan.

Labadie, J. 2006. MODSIM: River basin management decision support system. Chapter 23 in Watershed models. Boca Raton, Fla.: CRC Press.

Linsley, R. K., J. B. Franzini, D. L. Freyberg, and G. Tchobanoglous. 1992. Water resources engineering. New York: McGraw-Hill.

Makin, M.J., Kingham, T.J., Waddams, A.E., Birchall, C.J., Eavis, B.W., 1976. Prospects for irrigation development around Lake Zwai, Ethiopia.

Martínez-Casasnovas, J.A., Stuiver, H.J., (1998). Automatic delineation of drainage networks and elementary catchments from Digital Elevation Models. International Journal of Aerospace Survey and Earth Sciences (ITC Journal), 1998-3/4: 198-208.

Mesa, L.M (2006). Morphometric Analysis of a Subtropical Andean basin (Tucuman, Argentina). Environmental Geology, 50, pp.1235-1242.

Miller, V. C., (1953), A quantitative geomorphic study of drainage basin characteristics in the clinch mountain area, Technical report3, Department of Geology, Columbia University.

Moore, I. D., Grayson, R. B. and Ladson, A. R., (1977), Digital terrain modelling. In A Review ofHydrological, Geomorphological and Biological Applications (eds Beven, K. J. and More, I. D.),John Wiley, Chichester, pp. 7-31.

Nag S.K. and Chakraborty S., (2003). Influences of rock types and structures in the development of drainage network in hard rock area. J. Indian Soc Remote Sensing 33(1):25-35

Schumm, S. A., (1956), Evolution of drainage systems and slopes in Badlands at Perth Amboy, New Jersey, Geological Society of America, Bulletin, 67, pp 597646

Strahler, A.N. (1964). Quantitative geomorphology of drainage basins and channel networks,In: V.T. Chow (Ed.), Handbook of Applied Hydrology. McGraw Hill Book Company, New York,Section 4-11, pp. 439

\section{References}

Lawrence, S. et al. (2001). Persistence of Web References in Scientific Research. Computer. 34, $26-31$. doi:10.1109/2.901164, http://dx.doi.org/10.1109/2.901164

Smith, Joe, (1999), One of Volvo's core values. [Online] Available: http://www.volvo.com/environment/index.htm (July 7, 1999)

Strunk, W., Jr., \& White, E. B. (1979). The elements of style. (3rd ed.). New York: Macmillan, (Chapter 4).

Van der Geer, J., Hanraads, J. A. J., \& Lupton R. A. (2000). The art of writing a scientific article. Journal of Scientific Communications, 163, 51-59 


\section{Notes}

Note 1. This is an example.

Note 2. This is an example for note 2

Table 1 . The capitals, assets and revenue in listed banks

\begin{tabular}{|l|l|l|l|}
\hline & Total capital stock & Income of main business & Total assets \\
\hline Pudong Development Bank & 39.2 & 214.7 & 5730.7 \\
\hline Bank of China & 459.4 & 3345.7 & 59876.9 \\
\hline
\end{tabular}

Description for the above table.

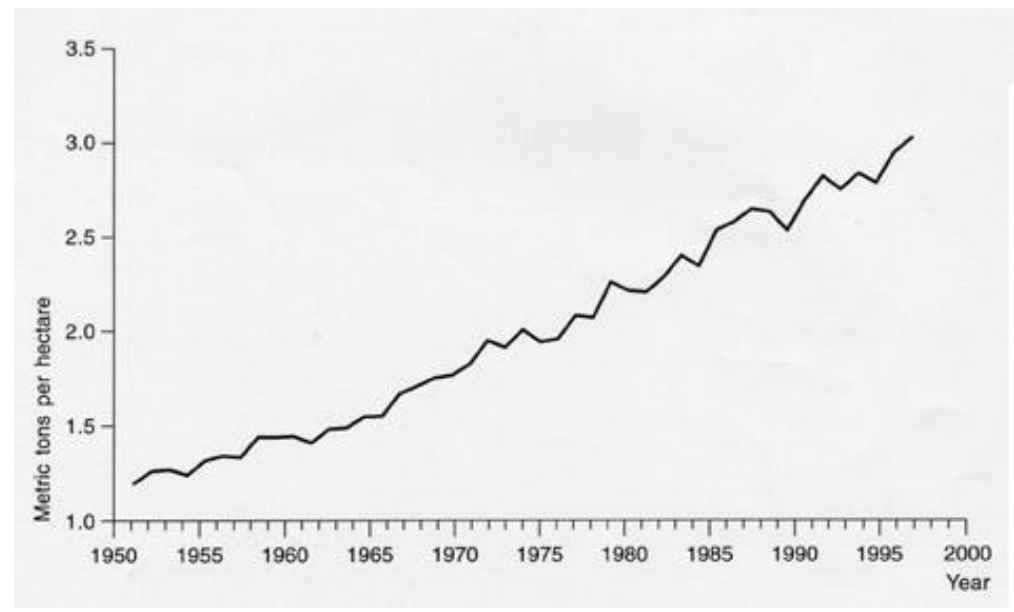

Figure 1. The Trend of Economic Development Description for the above figure. 